\title{
Use of Recycled Brick Masonry Aggregate and Recycled Brick Masonry Aggregate Concrete in Sustainable Construction
}

\author{
Dallas E. Schwerin, ${ }^{1}$ Tara L. Cavalline, ${ }^{2}$ and David C. Weggel ${ }^{3}$
}

Accepted February 1, 2013

\begin{abstract}
Use of recycled aggregates in portland cement concrete (PCC) construction can offer benefits associated with both economy and sustainability. Testing performed to date indicates that recycled brick masonry aggregate (RBMA) can be used as a 100\% replacement for conventional coarse aggregate in concrete that exhibits acceptable mechanical properties for use in structural and pavement elements, including satisfactory performance in some durability tests. Recycled brick masonry aggregate concrete (RBMAC) is currently not used in any type of construction in the United States. However, use of RBMAC could become a viable construction strategy as sustainable building practices become the norm. This paper explores the feasibility of use of RBMAC in several types of sustainable construction initiatives, based upon the findings of previous work with RBMAC that incorporates RBMA produced from construction and demolition waste from a case study site. A summary of material properties of RBMAC that will be useful to construction professionals are presented, along with a discussion of advantages and impediments to use. Several quality assurance and quality control techniques that could be incorporated into specifications are identified.
\end{abstract}

Keywords: Recycled Brick Masonry Aggregate, Sustainable Construction, Demolition Waste, Portland Cement Concrete

\section{INTRODUCTION}

A significant challenge facing the construction industry is management of construction and demolition (C\&D) waste. Often, C\&D waste is landfilled, consuming space that is becoming increasingly costly and scarce. An alternative to landfilling $\mathrm{C} \& \mathrm{D}$ waste is recycling and reuse. Conservation of landfill space, reduction of the environmental impact of producing new materials [1], and the reduction of overall project expenses can all be realized by recycling $\mathrm{C} \& \mathrm{D}$ waste [2]. Additionally, recycling of $C \& D$ waste can potentially create new jobs [3].

One means of recycling hardscape and structural C\&D waste is by crushing it into aggregates. Depending on the recycled aggregate's physical properties, recycled aggregates can be used in a variety of construction applications and can reduce dependence on natural aggregates [4]. For aggregates used in portland cement concrete (PCC), use of recycled C\&D waste in new concrete construction results in a decrease in both the amount of waste landfilled and the amount of primary aggregate extracted, thus reducing the environmental impact of the new construction [5].
Recycled concrete aggregate (RCA) has been used in a variety of construction applications, including temporary roads, fill material, and as a replacement of virgin concrete aggregates (both fine and coarse). Although many agencies have developed some level of comfort with RCA, crushed brick is not traditionally used as an aggregate in construction in the United States.

Aggregates produced using crushed bricks and crushed brick masonry have been used in new construction applications in several locations worldwide, but often in low grade applications [6]. However, increased interest in using crushed recycled brick and brick masonry has been shown by several researchers in recent years, especially for pavement applications $[7,8,9,10]$. When recycled brick masonry aggregate (RBMA) is utilized in concrete, the resulting concrete mixture can be referred to as recycled brick masonry aggregate concrete (RBMAC) [10]. As economical sources of natural aggregates become scarce and sustainable construction practices become increasingly popular, use of RBMA and RBMAC may become viable options in sustainable construction initiatives, diverting a portion of brick masonry rubble from landfills.

\footnotetext{
Graduate Student, Department of Engineering Technology and Construction Management, University of North Carolina at Charlotte, email: deschwer@uncc.edu

${ }^{2}$ Assistant Professor, Department of Engineering Technology and Construction Management, University of North Carolina at Charlotte, email: tcavalline@uncc.edu (*Corresponding Author)

${ }^{3}$ Associate Professor, Department of Civil and Environmental Engineering, University of North Carolina at Charlotte, email: dcweggel@uncc.edu
} 
Use of masonry rubble as aggregate is far from a novel idea. After World War II, many buildings in Europe were built using concrete that included aggregate produced by crushing the masonry rubble created by the war [11]. Use of this rubble fulfilled the need for building materials and reduced site-clearing costs [12]. Once the supply of rubble from World War II was exhausted, use of recycled brick masonry as aggregate in new construction appears to have stopped in Europe.

In other locations such as Iran and Bangladesh, natural aggregate sources are scarce, and bricks are produced for the purpose of crushing into aggregate [13]. In these locations, studies on RBMA and RBMAC have indicated that RBMA can be used while still maintaining suitable PCC performance. Major differences between RBMA and virgin aggregates have been found to be the angular shape and a higher absorption rate for RBMA [14].

In the United States, incentives for use of recycled materials in building construction have been provided by the Leadership in Energy and Environmental Design (LEED) building rating system. However, a number of impediments to the widespread use of recycled materials in new concrete and other cementitious materials exist, including obtaining the proper type and quantity of the desired material, preventing the introduction of unwanted contaminant materials into the RBMA, and ensuring that suitable RBMAC properties are achieved. A key impediment to using recycled aggregate produced using crushed brick masonry is the lack of knowledge of performance of brick aggregate concrete [15].

Several factors related to both the demolition site and source material characteristics can affect the quality of RBMA and ultimately affect the quality of RBMAC. Guidance for quality assurance and quality control programs (QA/QC) would assist producers, designers, and contractors utilizing RBMA and RBMAC. In this paper, a case study about the production and use of RBMA and RBMAC is presented, along with a summary of material properties for RBMA and RBMAC produced using the case study demolition waste. Suggestions for QA/QC and guidance for specifications for demolition, production of RBMA, and production of RBMAC are introduced.

\section{ANALYSIS OF CASE STUDY}

In order to obtain the "cleaneste demolished brick masonry that can be achieved via readily employable source separation techniques, RBMA was made from brick masonry obtained from a single demolition site, Idlewild Elementary School, located in Charlotte, North Carolina. This case study site was selected for use in a United States Department of Energy (DOE) research grant, in which UNC Charlotte researchers found reuse for several types of demolition waste. Findings of this study are presented in Weggel et al. [3]. As part of this study, several brick masonry walls that were demolished were utilized to produce RBMA, which was then used as a replacement for conventional coarse aggregates in RBMAC [10].

\section{A. Demolition}

UNC Charlotte personnel monitored the demolition process of the brick masonry walls, loading and transport to a local crushing yard, and final transport to UNC Charlotte laboratories. Additional details on the demolition process at this case study site, as well as a discussion on incentives and impediments to use of recycled aggregates from demolition waste, are presented by Tempest et al. [6].

At the case study site, the demolition contractor utilized a "top-down" demolition approach. This approach allows the slab-on-grade to remain in place until the end of demolition operations, facilitating a "clean" working surface for separation and collection of the demolished brick rubble as well as other recycled building materials. Components such as sheetrock, acoustical tile, roof material, and other interior building components were removed prior to demolition of the brick masonry walls. The "top-down" demolition process follows the general steps outlined below:

1. Removal of hazardous materials such as asbestos.

2. Removal of valuable metals such as copper and non-critical steel structures (such as awnings).

3. Demolition of non-masonry partition walls, drop ceilings, and fenestration.

4. Collection and disposal of materials listed in \#3.

5. Demolition and removal of roof framing, decking, and covering.

6. Demolition and removal of masonry partition walls.

7. Demolition and removal of the concrete slab.

Prior to transportation to the crushing and grading facility, the brick rubble produced from the demolition was stored on-site, separated from other materials. Transportation to the crushing and grading facility utilized clean dump trucks and only the brick masonry rubble was transported in each load.

\section{B. RBMA Production and Characterization}

In order to successfully reuse $C \& D$ waste, the characteristics of the source material must be determined. Therefore, a number of whole clay brick and tile were removed from the pile of demolished brick masonry at the case study site, and tests to characterize the materials were performed. These tests were to determine unit weight, compressive strength, modulus of rupture, absorption, and initial suction. Tests were performed in accordance with ASTM C67, "Standard Test Methods for Sampling and Testing Brick and Structural Clay Tile." Results of this testing are presented in Cavalline [10]. Mechanical properties of the brick and clay tile from the case study site are within the expected ranges as published by the Brick Institute of America [16], the American Concrete Institute [17], and other researchers [18].

The majority of the demolished brick masonry from the case study site was transported to the demolition contractor's crushing and grading facility. During the 
crushing and grading process, the RBMA was mechanically separated into three gradations: AASHTO M85 \#57, AASHTO M43 \#78, and fine aggregate. A portion of the \#78 material was removed from the stockpile and returned to UNC Charlotte for testing. At UNC Charlotte's laboratories, the \#78 aggregate was washed, and tests to characterize the RBMA were performed. Results of this testing are summarized in Table 1.

TABLE I

Characterization of CRUShed Brick MasonRy Aggregate

\begin{tabular}{l|c|c}
\hline Characteristic & Test Method & Result \\
\hline Gradation & ASTM C136 & AASHTO M43 \# 78 \\
\hline $\begin{array}{l}\text { Loose bulk density (unit } \\
\text { weight) }\end{array}$ & ASTM C29 & $\begin{array}{c}976 \mathrm{~kg} / \mathrm{m}^{3} \\
\left(60.9 \mathrm{lb} / \mathrm{ft}^{3}\right)\end{array}$ \\
\hline Specific gravity & ASTM C29 & 2.19 \\
\hline Absorption (\%) & ASTM C127 & 12.2 \\
\hline Abrasion Loss (\%) & ASTM C131 & 43.1 \\
\hline
\end{tabular}

When the results from Table 1 were compared to locally available sources of aggregates, it was found that RBMA has a significantly lower unit weight than local natural aggregates. However, the unit weight of the RBMA is slightly higher than the upper limit for lightweight aggregates as defined in ASTM C330, "Standard Specification for Lightweight Aggregates for Structural Concrete." The absorption and abrasion loss values were also higher than those of local natural and manufactured lightweight aggregates.

One of the more influential factors on the quality of RBMA is the "cleanliness" of the crushed brick rubble. Table 2 provides a breakdown of the materials present in the sample from the case study. As shown in the table, some contaminant material was present in the RBMA despite use of the top-down demolition sequence and source separation techniques. However, it is likely that not following these techniques would have led to more contaminants in the demolished rubble, further reducing the quality of the RBMA.

TABLE II

COMPOSITION OF THE RBMA PRODUCED From CASE STUDY DEMOLITION WASTE

\begin{tabular}{l|c|c}
\multicolumn{3}{c}{ DEMOLITION WASTE } \\
\hline \multicolumn{1}{c|}{ Material } & $\begin{array}{c}\% \text { by } \\
\text { Weight }\end{array}$ & $\begin{array}{c}\% \text { by } \\
\text { Volume }\end{array}$ \\
\hline Clay brick & 64.5 & 63.9 \\
\hline Clay tile & 2.1 & 1.9 \\
\hline Mortar & 30.1 & 31.6 \\
\hline $\begin{array}{l}\text { Other } \\
\text { (rock, porcelain, lightweight debris) }\end{array}$ & 3.3 & 2.6 \\
\hline
\end{tabular}

It is important to note that mortar comprises approximately $1 / 3$ of the RBMA, both by weight and volume. It is likely that this large amount of mortar affects the performance of the RBMA in concrete mixtures; however, in virtually all previous studies the presence of mortar is largely ignored. Studies to evaluate the influence of mortar on the performance of RBMAC are warranted.

\section{RBMAC Production and Testing}

Although the RBMA is slightly heavier than the upper limit for ASTM C330 lightweight aggregates, the high absorption of the RBMA led to the use of concrete mixture proportioning procedure outlined in ACI 211.2, "Standard Practice for Selecting Proportions for Structural Lightweight Concrete" (Method 1: Weight Method). After a number of trial mixtures were developed and tested, four baseline mixtures with varying cement contents, water reducing admixtures, and water/cement ratios were produced. Information on the development of the RBMAC mixture designs, the test results for mechanical properties, and the test results for durability performance are presented in Cavalline [10].

To provide a summary of the mechanical properties that can be obtained for RBMAC, mixture proportions and mechanical properties of two baseline mixtures, BAC 5.0 and BAC 6.0, were selected to be included in this paper. As shown in Table 3, these two RBMAC mixture designs have the same cement content (675 pcy), but one mixture (BAC 6.0) utilizes a high-range water reducing admixture, while the other mixture (BAC 5.0) does not.

TABLE III

RBMAC ProducEd From CASE STUdy AgGREgATE

\begin{tabular}{|c|c|c|c|}
\hline & \multicolumn{2}{|c|}{ Mixture ID } \\
\hline & & BAC 5.0 & BAC 6.0 \\
\hline \multirow{7}{*}{ 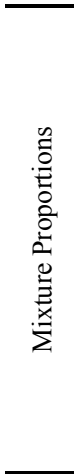 } & Coarse aggregate & $\begin{array}{c}699.2 \mathrm{~kg} / \mathrm{m}^{3} \\
\left(1,178.6 \mathrm{lb} / \mathrm{yd}^{3}\right)\end{array}$ & $\begin{array}{c}699.2 \mathrm{~kg} / \mathrm{m}^{3} \\
\left(1,178.6 \mathrm{lb} / \mathrm{yd}^{3}\right)\end{array}$ \\
\hline & Sand & $\begin{array}{c}768.9 \mathrm{~kg} / \mathrm{m}^{3} \\
\left(1,296.0 \mathrm{lb} / \mathrm{yd}^{3}\right)\end{array}$ & $\begin{array}{c}768.9 \mathrm{~kg} / \mathrm{m}^{3} \\
\left(1,296.0 \mathrm{lb} / \mathrm{yd}^{3}\right) \\
\end{array}$ \\
\hline & Cement & $\begin{array}{c}400.5 \mathrm{~kg} / \mathrm{m}^{3} \\
\left(675.0 \mathrm{lb} / \mathrm{yd}^{3}\right)\end{array}$ & $\begin{array}{c}400.5 \mathrm{~kg} / \mathrm{m}^{3} \\
\left(675.0 \mathrm{lb} / \mathrm{yd}^{3}\right)\end{array}$ \\
\hline & Water & $\begin{array}{r}173.2 \mathrm{~kg} / \mathrm{m}^{3} \\
\left(292.0 \mathrm{lb} / \mathrm{yd}^{3}\right) \\
\end{array}$ & $\begin{array}{c}128.1 \mathrm{~kg} / \mathrm{m}^{3} \\
\left(216.0 \mathrm{lb} / \mathrm{yd}^{3}\right) \\
\end{array}$ \\
\hline & Water/cement ratio & 0.43 & 0.32 \\
\hline & $\begin{array}{l}\text { Air entraining } \\
\text { admixture }\end{array}$ & $\begin{array}{c}405 \mathrm{~mL} \\
(13.7 \mathrm{oz})\end{array}$ & $\begin{array}{c}485 \mathrm{~mL} \\
(16.4 \mathrm{oz})\end{array}$ \\
\hline & $\begin{array}{l}\text { High-range water } \\
\text { reducing admixture }\end{array}$ & $\begin{array}{l}0 \mathrm{~mL} \\
(0 \mathrm{oz})\end{array}$ & $\begin{array}{l}1079 \mathrm{~mL} \\
(36.5 \mathrm{oz})\end{array}$ \\
\hline \multirow{2}{*}{ 贾 } & Slump & $\begin{array}{c}152.4 \mathrm{~mm} \\
(6.0 \mathrm{in}) \\
\end{array}$ & $\begin{array}{c}139.7 \mathrm{~mm} \\
(5.5 \mathrm{in}) \\
\end{array}$ \\
\hline & Air content $(\%)$ & 5.50 & 7.50 \\
\hline \multirow{8}{*}{ 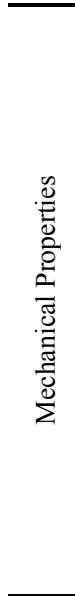 } & $\begin{array}{l}\text { 3-day compressive } \\
\text { strength }\end{array}$ & $\begin{array}{c}14.7 \mathrm{MPa} \\
(2,139 \mathrm{psi})\end{array}$ & $\begin{array}{c}31.4 \mathrm{MPa} \\
(4,559 \mathrm{psi})\end{array}$ \\
\hline & $\begin{array}{l}\text { 7-day compressive } \\
\text { strength }\end{array}$ & $\begin{array}{c}19.7 \mathrm{MPa} \\
(2,858 \mathrm{psi})\end{array}$ & $\begin{array}{l}42.6 \mathrm{MPa} \\
(6,182 \mathrm{psi}) \\
\end{array}$ \\
\hline & $\begin{array}{l}\text { 28-day } \\
\text { compressive } \\
\text { strength }\end{array}$ & $\begin{array}{c}25.3 \mathrm{MPa} \\
(3,675 \mathrm{psi})\end{array}$ & $\begin{array}{l}44.8 \mathrm{MPa} \\
(6,497 \mathrm{psi})\end{array}$ \\
\hline & $\begin{array}{l}\text { 90-day } \\
\text { compressive } \\
\text { strength }\end{array}$ & $\begin{array}{l}26.7 \mathrm{MPa} \\
(3,872 \mathrm{psi})\end{array}$ & $\begin{array}{c}47.6 \mathrm{MPa} \\
(6,903 \mathrm{psi})\end{array}$ \\
\hline & $\begin{array}{l}\text { 7-day modulus of } \\
\text { elasticity }\end{array}$ & $\begin{array}{c}19.0 \mathrm{GPa} \\
(2,753,000 \mathrm{psi})\end{array}$ & $\begin{array}{c}27.4 \mathrm{GPa} \\
(3,977,000 \text { psi) }\end{array}$ \\
\hline & $\begin{array}{l}\text { 7-day Poisson's } \\
\text { ratio }\end{array}$ & 0.21 & 0.17 \\
\hline & $\begin{array}{l}\text { 7-day modulus of } \\
\text { rupture }\end{array}$ & $\begin{array}{l}3.58 \mathrm{MPa} \\
(519 \mathrm{psi})\end{array}$ & $\begin{array}{l}5.50 \mathrm{MPa} \\
(797 \mathrm{psi})\end{array}$ \\
\hline & $\begin{array}{l}\text { 28-day splitting } \\
\text { tensile strength }\end{array}$ & $\begin{array}{l}2.21 \mathrm{MPa} \\
(320 \mathrm{psi})\end{array}$ & $\begin{array}{l}3.03 \mathrm{MPa} \\
(439 \mathrm{psi})\end{array}$ \\
\hline
\end{tabular}


Results indicate that RBMAC mixtures can exhibit acceptable structural- and pavement- grade characteristics, particularly when a water-reducing admixture is utilized. The equilibrium density of mixture BAC 5.0 was $1791 \mathrm{~kg} / \mathrm{m} 3 \quad(111.8 \mathrm{lb} / \mathrm{ft} 3)$, and the equilibrium density of BAC 6.0 was $2054 \mathrm{~kg} / \mathrm{m} 3(128.2$ $\mathrm{lb} / \mathrm{ft} 3)$. These densities are both less than the unit weight of conventional normalweight concrete. As part of the work by Cavalline [10], the suitability of RBMAC for use in pavement applications was evaluated and the potential performance of RBMAC pavement was compared to conventional PCC pavement. Analyses indicated that acceptable performance in pavement applications using slightly thinner pavement sections resulted from using RBMAC.

\section{INCENTIVES FOR USE}

Use of recycled aggregates, including RBMA, in portland cement concrete can offer benefits associated with both economy and sustainability. A number of benefits will be realized by reducing the amount of construction and demolition materials disposed of in landfills. Fewer new disposal facilities will be required, fewer virgin resources will be extracted and consumed, and entities can obtain tax advantages if recycled material is used for (or donated to) charity [2]. Reducing and recycling construction and demolition waste materials conserves landfill space, reduces the environmental impact of producing new materials, can create jobs, and can reduce overall building project expenses through avoided purchase/disposal costs [2].

Key incentives for owners, project managers, and general contractors to find alternative uses for $C \& D$ waste are related to sustainable construction. The United States Green Building Council (USGBC) offers incentives for reuse of $C \& D$ waste through the Leadership in Energy and Environmental Design (LEED) Green Building Rating System. Points are offered in the LEED rating system for construction waste management, materials reuse, recycled content, and use of locally acquired material [19]. Green Globes, developed in Canada and introduced in the United States in 2004, is another sustainable construction rating system that offers incentives for reuse of construction materials [20]. Use of C\&D material in sustainable construction can provide a new source of revenue for general contractors and companies involved in sustainable construction.

\section{Potential USES}

Currently, recycled aggregate is being used in many new construction projects, both non-structural and structural applications. RCA is being used as a fill material, as backfill and foundation in trench applications, and in temporary roads and construction entrances. However, use of RCA as coarse aggregate in new concrete is often limited to low-grade applications [6]. Many agencies, such as the North Carolina Department of Transportation (NCDOT) are developing an increased comfort level with RCA and incorporating additional allowed uses into their specifications [10].

In the United States, RBMA has currently been limited to landscaping applications, use as a sub-base material in pavement applications, and limited use (outside the United States) as an aggregate in concrete. Other applications in which RBMAC could be used include precast concrete, sidewalks, curb and gutter, paving applications, and even possibly as structural members. The color of RBMA can provide an aesthetically pleasing appearance for certain pre-cast concrete applications. Exterior facades, walkways, and pavements can be architecturally designed to provide new and interesting appearances for buildings. For projects utilizing the material in re-use applications, not only does this material provide points in the LEED certification system, re-use of this material can expand the historic and nostalgic aspects of a particular project.

\section{Potential ISSUES}

In many cases, recycling only takes place when use of C\&D waste provides economic advantages to stakeholders. This occurs when beneficial reuse is cheaper than landfilling, and (in the case of recycled aggregates) when users of construction aggregates find recycled aggregates of similar quality cheaper than newly quarried aggregates [1]. Potential costs incurred by design and construction professionals desiring to use RBMA and RBMAC include costs associated with crushing (using either a mobile crushing unit or hauling/crushing at a recycled aggregate producer), with storage of the demolished masonry and/or RBMA, with characterization of whole brick and RBMA, and with development and testing of RBMAC.

The Florida Department of Environmental Protection (DEP) [21] indicates that the practice of separating and processing waste at the construction and demolition job site itself has been limited because of tight economic margins and the need for rapid completion of the project. According to Florida DEP [21], a major factor influencing the success of a recycling operation is the degree of contamination of the material. The DEP further states that aggressive handling of the recycled material at some processing facilities has been linked to an increase in the amount of impurities present. The presence of hazardous materials in the recycled material may also limit the reuse options [21]. Suppliers can charge higher prices for recycled material that contains less contaminant material, as it is a more desirable product than recycled material with more contaminant material.

An important aspect that must be considered before using a recycled material is the availability of that material in large quantities, if needed. To aid in a more uniform performance of RBMA (and subsequently RBMAC), use of material from a single demolition source is desirable. With same-site reuse of RBMA, the RBMA would be produced from a known quantity of demolished brick masonry, and this may not be an issue. 
Same-site use may be of particular interest in sustainable construction projects pursuing LEED certification.

One of the most prominent risks perceived by a designer/contractor regarding the use of recycled aggregates in concrete is related to the consistency of the recycled aggregate source. At the Idlewild Elementary School case study site, it was found that top-down demolition techniques paired with on-site source separation of demolition debris can facilitate the generation of RBMA that is relatively "clean" and free of debris. It has been shown that in small quantities, the presence of contaminants can be ignored, as the contaminants do not significantly detract from the performance of RBMAC [10]. Quality control techniques to ensure the integrity of RBMA could prove more costly for certain projects where virgin "clean" aggregates are in close proximity to the site and are readily available for use in new concrete.

According to Rao et al. [22], challenges to the acceptance of recycled aggregates in concrete applications are generally related to a lack of awareness about the recycled content, a lack of government support promoting the use of recycled aggregates, and a lack of code guidance or specifications for reuse in new concrete. Ultimately, for RBMA to be considered as a viable aggregate source, guidelines for tests to ensure acceptable material properties and performance characteristics will need to be developed. Based on the findings from the case study site, some suggestions for specifications are provided in subsequent sections of this paper.

\section{QUALity Assurance Program}

In order to ensure that the RBMA and RBMAC will be suitable for use in new construction, a quality assurance program should be developed and implemented for the project. Quality assurance programs for projects where RBMA and RBMAC will be utilized should include the designation of an individual (Quality Manager) responsible for oversight of the aspects of demolition, handling, and production of RBMA and RBMAC. Duties of this Quality Manager should include both oversight and documentation of operations related to the process. The Quality Manager should work integrally with the project manager for the general contractor, as well as with the demolition contractor, to ensure that jobsite personnel involved with handling the demolition waste and production of the RBMA and RBMAC are familiar with the governing $\mathrm{QA} / \mathrm{QC}$ measures.

Ultimately, quality is the responsibility of all members of the project team. Active participation by the general contractor and the demolition contractor is required. Quality assurance programs should include provisions to ensure that site personnel are familiarized with procedures for demolition sequencing, source separation techniques, the locations of stockpiles and/or storage containers for recycled materials, measures utilized to protect the integrity of source-separated material, and related safety concerns. Responsibilities for training and oversight should also be outlined in the quality assurance program.

Prior to specifying that RBMA and/or RBMAC be produced from demolition waste from a site, testing should be performed to characterize the whole brick and masonry rubble. A sampling and testing plan should be developed to ensure that the bricks selected for testing are a realistic representation of bricks present at the site. If available, documentation should include the manufacturer of the whole brick, location of the manufacturing plant, and information about the raw materials used in the production of the whole brick. This information could prove to be valuable to other professionals interested in using RBMA and/or RBMAC from the same (or a similar) source.

Quality assurance programs should include provisions to ensure that adequate room for separation and storage of the demolished brick masonry are available on site. The QA/QC technician should work with the general contractor to identify an appropriate area either on-site or locally off-site to support operations necessary for separation of the materials to be recycled. If space constraints at the project site prove to be problematic for the quantity of material to be recycled, containers could be used to facilitate source-separation of the materials. Provisions for periodic visual inspection of material stockpiles and/or recycling bins should be included in the quality assurance program. If stockpiles are used, it is important to provide provisions in specifications that ensure that piles are maintained in a manner that minimizes the possibility of contaminants (including other building materials) being introduced into the pile.

If the size, location, schedule, and other constraints of a project allow, the "top-down" demolition approach should be utilized. Quality control procedures to be enforced at the crushing and grading facility should be identified and incorporated in the project's quality assurance program. Quality control measures to be implemented during the crushing and grading process used to produce the RBMA and during production and placement of the RBMAC should also be included in the quality assurance program.

\section{GUIDANCE FOR SPECIFICATIONS FOR PRODUCING RBMA AND RBMAC}

Quality assurance and quality control measures for RBMA and RBMAC have not been established or adopted by agencies in the United States. Guidance for project specifications would be helpful to designers and other project stakeholders interested in using RBMA and RBMAC in sustainable construction. The provisions outlined below are suggested to be included in the appropriate sections of project specifications.

Prior to approval of use of RBMA and RBMAC for a project site, tests should be performed to ensure that whole brick, RBMA, and RBMAC are of suitable quality for use in new concrete construction. The testing program could include the tests listed below. The actual tests included in the specifications should be those that help to 
ensure that the RBMA and RBMAC meet the requirements of the designer. Tests should be performed in a controlled laboratory setting by qualified laboratory technicians.

TABLE IV

RECOMMENDED TESTS FOR WHOLE BRICK, RBMA, AND RBMAC FOR Use In SPECIFICATIONS

\begin{tabular}{c|l|c}
\hline Material & Property or Characteristic & Test Method \\
\hline \multirow{4}{*}{ Whole brick } & Compressive strength & \multirow{4}{*}{ ASTM C67 } \\
\cline { 2 - 2 } & Modulus of rupture & \\
\cline { 2 - 2 } & Absorption & ASTM C136 \\
\cline { 2 - 2 } & Suction & \multirow{2}{*}{ ASTM C127 } \\
\hline \multirow{4}{*}{ RBMA } & Gradation & ASTM C29 \\
\cline { 2 - 3 } & Absorption & ASTM C131 \\
\cline { 2 - 3 } & Specific gravity & ASTM C43 \\
\cline { 2 - 3 } & Bulk density & ASTM C138 \\
\cline { 2 - 3 } $\begin{array}{c}\text { RBMAC } \\
\text { (fresh) }\end{array}$ & Abrasion resistance & ASTM C39 \\
\cline { 2 - 3 } & Alump & ASTM C469 \\
\hline \multirow{4}{*}{$\begin{array}{c}\text { RBMAC } \\
\text { (hardened) }\end{array}$} & Compressive strength & ASTM C48 \\
\cline { 2 - 3 } & Modulus of elasticity & ASTM C1202 \\
\cline { 2 - 3 } & Modulus of rupture & Splitting tensile strength \\
\cline { 2 - 3 } & $\begin{array}{l}\text { Rapid chloride ion } \\
\text { permeability }\end{array}$ & \\
\hline
\end{tabular}

Additional guidance for specifications for producing RBMA and RBMAC are provided below.

For a demolition/renovation project with adequate space for stockpiling materials:

1. Demolition should be sequenced in a manner that facilitates source separation of materials that will be recycled. "Top-down" demolition sequencing should be utilized.

2. Demolition Contractor should stockpile materials onsite in a manner that prevents intermingling of different demolished building components as well as prevents contamination from subgrade. Suggested courses of action are the following:

a. Use of on-site recycling/waste containers.

b. Use of an existing concrete slab-on-grade to offer a "clean" area for source separation.

c. Transporting other materials off-site immediately after demolition.

For a demolition/renovation project without adequate space for stockpiling materials:

1. Demolition Contractor should determine the approximate quantity of each material that will be recycled. Appropriately sized containers should be acquired for use in separating and storing each material to be recycled.

2. Demolition Contractor should coordinate and manage the inflow and outflow of recycled materials in a manner that conserves space and prevents intermingling of different types of materials. Other materials should be transported off-site immediately after demolition.
For projects where RBMA is to be produced from demolished brick masonry, specifications should include the following provisions:

1. Demolition contractor should inform all employees on the project of the recycling goals for that project.

2. Trucks used to haul demolished material to a crushing and grading facility should be free from other construction materials and residue.

3. At the crushing and grading facility, demolished brick masonry should be stockpiled separately from other materials, in a manner that prevents intermingling of materials as well as prevents contamination from the subgrade.

Additionally, to help control the quality of RBMA and the RBMAC it produces, designers could choose to specify that mobile crushers be used to produce RBMA on-site and specify use of on-site concrete batching equipment to produce the RBMAC.

Specifications should include the following provisions for activities at the crushing and grading facility:

1. Material from the subject project should be kept separate from materials from other sites. If other hardscape or structural materials (such as concrete, concrete masonry, or other rubble) are to be delivered from the same site for crushing and grading, provisions should be made to ensure that they do not intermingle with the demolished brick masonry.

2. Stockpiles should be kept free from debris and contamination from other materials.

3. Prior to crushing and grading of the demolished brick masonry, crushing and grading equipment should be free from residue from other previously crushed materials.

4. RBMA to be utilized in RBMAC should be washed to remove excess fine material produced during the crushing operation.

Specifications should include the following provisions for activities related to production of RBMAC:

1. RBMA should be tested to determine physical properties necessary for the development of the RBMAC mixture designs.

2. Mixture proportions should be determined in accordance with ACI 211.2, with RBMA batched in a saturated surface dry (SSD) condition.

3. The proposed RBMAC mixture should be tested for mechanical and durability properties as required by the project engineer. The project engineer should be responsible for approval of the proposed RBMAC mixture.

4. During construction, RBMAC should be batched with the RBMA in a presoaked condition, with excess moisture accounted for during dosing of water to the concrete mixture. Provisions for testing fresh and hardened concrete properties should be included in project specifications, so it can be confirmed that the RBMAC meets the designer's requirements. 


\section{CONCLUSIONS}

Use of recycled aggregates in PCC can offer benefits associated with both economy and sustainability. Significant research has been performed on use of RCA in concrete elements, but until recently, use of RBMA has not been studied in the United States. As landfill space becomes increasingly scarce, and tipping fees continue to rise, the need to find alternative uses for demolition waste becomes more pronounced. RBMA has been shown to be a viable material for use in structural and pavement grade concrete, possessing mechanical properties similar to those of PCC with conventional aggregates.

Potential advantages of using RBMAC include reduction in the use of virgin aggregates, lower embodied energies of concrete elements, and possibly, project cost savings and creation of jobs. However, due to risks inherent in using this (and any) waste material in new construction, guidance in the form of standards and specifications is important. A quality program should be developed prior to initiating work at the site in order to ensure that adequate $\mathrm{QA} / \mathrm{QC}$ measures related to RBMA and RBMAC production are utilized during all stages of the project. The suggested provisions for specifications, as presented in this paper, should assist stakeholders interested in utilizing RBMA and RBMAC in sustainable construction projects.

\section{ACKNOWLEDGEMENTS}

This material is based upon work supported by the Department of Energy under Award Number DE-FG2608NT01982. D.H. Griffin Companies obtained, transported, and processed the material used in this research, and their assistance (especially that of Mark Greene) is greatly appreciated.

Note: This paper was originally published as the conference paper in the ICCEPM 2013 and awarded as one of the best papers. Through a rigorous review process, the paper has been invited to be a special version of JCEPM.

\section{REFERENCES}

[1] X. Duran, H. Lenihan, B. O'Regan, "A model for assessing the economic viability of construction and demolition waste recycling - the case of Ireland", Resources, Conservation and Recycling, vol. 46, no. 3, pp. 302-320, 2006.

[2] United States Environmental Protection Agency (EPA), available at www.epa.gov, (accessed 24 September 2012), 2012.

[3] D.C. Weggel, S.E. Chen, H. Hilger, F. Besnard, T. Cavalline, B. Tempest, A. Alvey, M. Grimmer, R. Turner, "Final Scientific Report: Building Materials Reclamation Program”, Department of Energy (DOE), Project \#DE-FG26-08NT01982, 2011.

[4] M. Hiete, J. Stengel, J. Ludwig, F. Schultmann, "Matching construction and demolition waste supply to recycling demand: A regional management chain model", Building Research and Information, vol. 39, no. 4, pp. 333-351, 2011.

[5] J.D. Thompson, H.H. Bashford, "Concrete Recycling and Utilization of Recycled Concrete", Construction Research Congress 2012, American Society of Civil Engineers, pp. 1682$1688,2012$.

[6] B. Tempest, T. Cavalline, J. Gergely, D. Weggel, "Construction and Demolition Waste Used as Recycled Aggregates in Concrete: Solutions for Increasing the Marketability of Recycled Aggregate
Concrete", Proceedings of the Concrete Sustainability Conference, Tempe, AZ, USA, 2010.

[7] Y. Wu, Y. Guo, X. Zhang, "Application of recycled brick-stone aggregate in road base", Proceedings of the 2009 GeoHunan International Conference - Material, Design, Construction, Maintenance, and Testing of Pavement, Changsha, Hunan, China, pp. 43-48, 2009.

[8] T. Aatheesan, A. Arulrajah, J. Wilson, M.W. Bo, "Beneficial use of brick rubble as pavement sub-base material", Proceedings of the 1st International Conference on Transportation Geotechnics, Nottingham, UK, pp. 695-699, 2008.

[9] A. Arulrajah, J. Piratheepan, T. Aatheesan, M.W. Bo, "Geotechnical Properties of Recycled Crushed Brick in Pavement Applications", Journal of Materials in Civil Engineering, vol. 23, no. 10, pp. 1444-1452, 2011.

[10] T. Cavalline, "Recycled Brick Masonry Aggregate Concrete: Use of Recycled Aggregates From Demolished Brick Masonry Construction in Structural and Pavement Grade Portland Cement Concrete", Ph.D. Dissertation, The University of North Carolina at Charlotte, 2012.

[11] T.C. Hansen, "Recycling of Demolished Concrete and Masonry. Report of Technical Committee 37-DRC Demolition and Reuse of Concrete", RILEM (The International Union of Testing and Research Laboratories for Materials and Structures), E\&FN Spon, London, 1992.

[12] F.M. Khalaf, A.S. DeVenny, "Properties of new and recycled clay brick aggregates for use in concrete", Journal of Materials in Civil Engineering, vol. 17, no. 4, pp. 456-464, 2005.

[13] A.H. Khan, J.R. Choudhury, "A rationale for making structural concrete using broken brick aggregate in Bangladesh", Proceedings of the International Conference on Materials of Construction for Developing Countries, Bangkok, Thailand, pp. 813-827, 1978.

[14] P. De Vries, “Concrete re-cycled", Concrete (London), vol. 27, no. 3, pp. 9-13, 1993.

[15] F. Debieb, S. Kenai, "The use of coarse and fine crushed bricks as aggregate in concrete", Construction and Building Materials, vol. 22, no. 5, pp. 886-893, 2008.

[16] Brick Industry Association, "Technical Notes 3A - Brick Masonry Material Properties", available at www.bia.org, (accessed February 2012), 1992.

[17] American Concrete Institute (ACI), "Guide to Thermal Properties of Concrete and Masonry Systems", ACI Committee Report 122R-02, 2002.

[18] R.E. Klingner, "Masonry Structural Design", McGraw Hill, New York, NY, USA, 2010.

[19] Leadership in Energy and Environmental Design (LEED), "LEED 2009 for New Construction and Major Renovations", available at www.usgbc.org, (accessed January 2012), 2009.

[20] K. Safwan, B. Tamer, E. Islam, "Brick Masonry and Sustainable Construction", Proceedings of the International Conference on Sustainable Design and Construction 2011: Integrating Sustainability Practices in the Construction Industry, Eds. W.K.O. Chong, C. Hermreck, Kansas City, MO, USA, pp. 524-534, 2012.

[21] Florida Department of Environmental Protection, available at www.dep.state.fl.us, (accessed: 24 September 2012), 2012.

[22] A. Rao, K.N. Jha, S. Misra, "Use of aggregates from recycled construction and demolition waste in concrete", Resources, Conservation and Recycling, vol. 50, no. 1, pp. 71-81, 2006. 